\title{
Development of Network Interactive Teaching Materials and Empirical in "Management" Courses
}

\author{
http://dx.doi.org/10.3991/ijet.v11i05.5690 \\ Xiaobo Jia ${ }^{1}$, Juying Huang ${ }^{2}$ \\ ${ }^{1}$ Chongqing Youth Vocational \& Technical College, Chongqing, China \\ ${ }^{2}$ Chongqing City Management Vocational College, Chongqing, China
}

\begin{abstract}
-network interactive teaching material utilizes multimedia technology for digital processing of traditional paper content and makes the teaching material suitable for various electronic terminals. Network interactive teaching material making is closely related to the development of distance teaching. This paper mainly takes Human Resource Management as the experimental course, utilizes teaching resource cloud platform of augmented reality interactive teaching materials for empirical study on the application of network interactive teaching material in Human Resource Management course, discusses the application effect of new distance education and teaching resources, offers theoretical and data support for development of network interactive teaching material and distance education and exploits potential development direction of future course construction.
\end{abstract}

Index Terms-network interactive teaching material, $\mathrm{Hu}$ man Resource Management, distance education, cloud platform

\section{INTRODUCTION}

The promotion of teaching quality is a key task in the period of popular education development. Teachers in various colleges are actively seeking effective teaching methods and trying to offer diversified and all-round leaning guidance for students [1]. Meanwhile, as information technology and education technology advance continuously, we must accelerate education informatization, enhance educational information infrastructure construction and pay attention to development and application of superior educational resources. Therefore, modern distance education based on information and network technology has become a hot issue concerned by numerous teaching researchers under the era of information technology. Modern distance education integrates optimized and combined teaching modes of multiple media, and its characteristics are as follows: students are separated from the teacher; teaching is implemented with the specific transmission system and media; rich information transmission mode; flexible learning place and form; low teaching cost [2].

Network teaching material applied by distance education is an important part of digital media content, digital publishing, digital reading and modern educational information service etc. [3]. Network interactive teaching material refers to electronic teaching material which presents teaching content by computer network technology and organically combines multimedia such as text, image, audio, video and virtual scene. Different from audio, video, courseware, CAI and other assisted teaching tools, network interactive teaching material is independent teaching material which does not depend on assisted teaching tools and can achieve comprehensive and complete learning of a course. Hence, it has certain interaction ability [4]. Good network teaching can provide learners with information environment and service for individualized learning and lifelong learning. Network teaching material is the foundation of improving distance education quality [5]. Educators can transmit course knowledge to the outside of the campus through audio and video in network teaching material as well as real-time and non-real-time computer technology so as to achieve teaching resource transmission and carry out diversified teaching through the computer linked to internet or other communication media as well as mobile phone and tablet PC etc.

With the development of information technology and the rise in the demand of information technology, network interactive teaching material presents a new development trend. Damanakis A used an improved network teaching material in the laboratory of medical teaching in order to improve students' practical ability through the network courseware [6]. Some researchers applied network teaching material in mathematics teaching. They summed up research results already gained about e-textbooks and investigated the key evolutions of its application - evolutions in the teaching and learning processes as well as evolutions in the concepts of quality and coherence, central for the design of the e-textbooks, and naturally for research, and obtained certain application effect [7]. In China, Li Famin and Xiao Fen combined portability and usability of tablet PC as well as multi-touch technology and good procedure operation ability to preliminarily explore interactive electronic teaching material in 2012 [8]. In 2013, Lin Junfen et al. started from examples of publishing circle, analyzed transformation of publishing industry in the digital era and focused on the form of interactive digital teaching material. As the researches on network interactive teaching material go deep increasingly, many scholars turn their eyes on design and construction of relevant platform [9]. Yu Shengquan et al. utilized generation and evolution features of learning cell platform resource to design and implement a course which was jointly constructed by the teacher and students, learned and taught mutually [10]. However, during the use of network teaching material, some problems exist universally. Firstly, if network teaching material which is matched with distance education is completely used, the making 
cost is high, and it is difficult for some teachers in noncomputer major to master such making technology. Secondly, due to the differences of disciplines, not all professional teaching materials can be electronized. In addition, classroom knowledge is updated continuously so that network teaching material cannot modify and add teaching content at the same time [11]. Thus, how to solve the above problem is the research direction we should focus on.

Based on research results of the above researchers, this paper designs a new network teaching material making mode in allusion to the defects of current network interactive teaching material. Besides, this paper also designs a teaching resource cloud platform matched with network teaching material. Since the network teaching material can achieve interaction and exchange among students and between students and teachers on the teaching resource cloud platform, we call it "network interactive teaching material" and apply it in the course of Human Resource Management. The improvement of network interactive teaching material lies in providing network interactive teaching material which owns instantaneity and can update teaching knowledge rapidly in order to solve teaching problems of traditional teaching material such as boringness, slow update of information and knowledge and poor interactivity. Meanwhile, it enhances convenience for teachers to use electronic technology. The network interactive teaching material can trigger relevant content in cloud database, and display exercises, teaching demonstration module and teaching experiment (also including course background and reference) in the teaching material according to the needs so as to further improve teaching effect of distance education and learning efficiency.

\section{MAKING AND DeSIGN Of Network INTERACTIVE TEACHING MATERIAL}

The development of modern information technology solves massive information recording, storage, transmission, display and processing problems. With stronger functions and lower cost, modern information technology provides brand-new idea and technology for network interactive teaching material making. The combination of multimedia characteristic, artificial intelligence technology and collaborative learning mode makes network interactive teaching material become the set of enormous knowledge information about course teaching.

\section{A. Multimedia and intelligence making}

During making network interactive teaching material, multimedia characteristics and artificial intelligence technology should be fully utilized to form intelligent multimedia teaching material. Multimedia refers to combination of audio-video technology, computer technology and communication technology in teaching material making [12]. Intelligence means under the support of high-speed logical judgment, operation capacity and quantities of multimedia databases, network interactive teaching material should own such functions as question answering, error diagnosis and virtual simulation and achieve realtime interaction with students.

\section{B. Collaboration and generation making}

Effective implementation of distance education cannot be separated from collaborative learning. In the collaboration process, students discuss, share and solve doubts. Interaction activities of diversified forms trigger cognition conflict among different individuals and promote mutual progress [13]. The making of network interactive teaching material adopts the form of collaborative knowledge building and course generation.

\section{Teaching resource library building}

Teaching resource library includes multimedia teaching resource library, micro-teaching unit library, virtual teaching resource library, data presentation mode library and teaching strategy library. (see figure 1)

Multimedia teaching resource library is based on knowledge points and sort the materials according to the sequence and classifying rules, including text, sound, picture, video, animation and other multi-dimensional information material libraries. Micro-teaching unit library is "small courseware" without cover design, redundant background and commentary dubbing, and it aims to help the teacher explain a difficult point in teaching or help students understand a knowledge point. Virtual teaching resource library adapts network globalization trend. And various teaching resources can be retrieved and recombined just by providing websites of resources. Data presentation mode library concludes and classified all kinds of data presentation modes and is designed as the mode easy for use and assignment. Teaching strategy library includes different teaching strategies so that the teacher can deal with various circumstances flexibly.

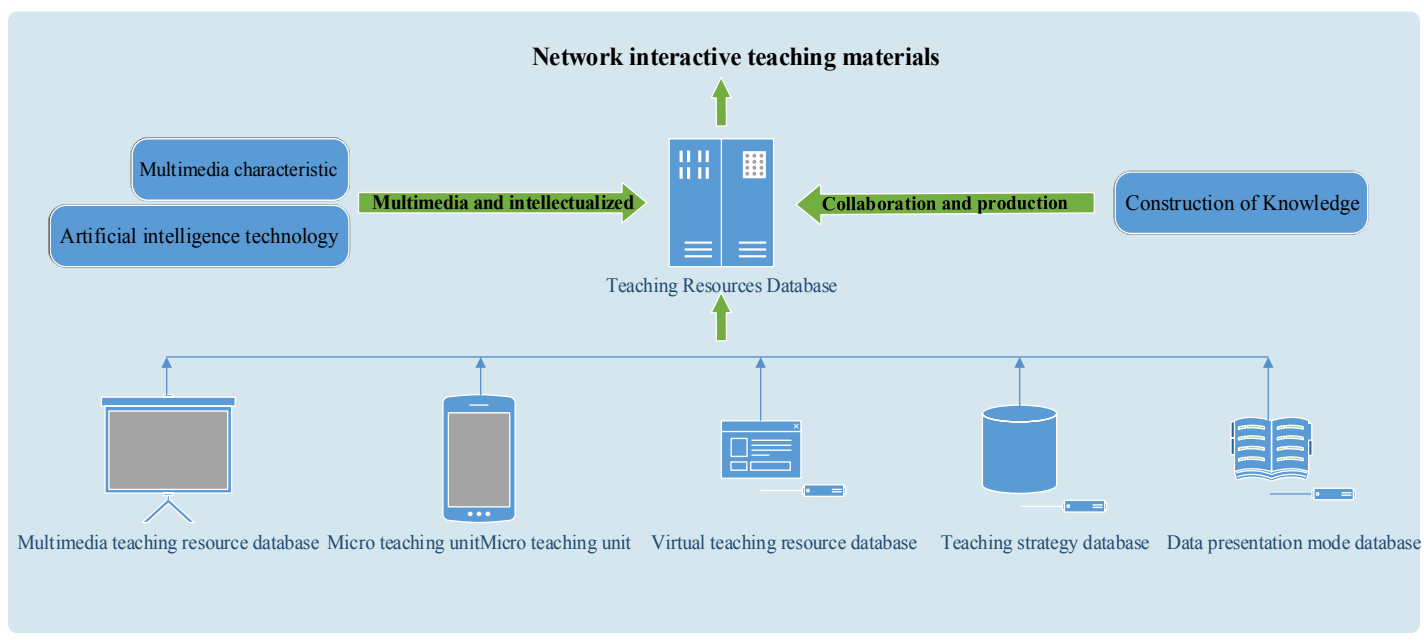

Figure 1. Making diagram of network interactive teaching material 


\section{Teaching resource cloud platform design of network interactive teaching material}

The application of network interactive teaching material is based on construction of teaching resource cloud platform. The platform can achieve multimedia of network interactive teaching material, resource globalization, learning independence and non-restriction of time and place and complete the whole teaching process. It is used by teachers and students to combine resource libraries and finally used in software environment of distance education.

The platform adopted in this research is teaching resource cloud platform of augmented reality interactive teaching material, including teaching material and teaching resource module, digital teaching material tool module and knowledge growth and accumulation module. Teaching material and teaching resource module involves teaching material framework module, supplementary teaching material module, teaching demonstration module and teaching experiment module. The contents include textbook, text outline, course background and reference etc. Simulation of teaching experiment and course content experiment can be conducted. Digital teaching material tool module toolkit module and cloud database module, and the contents contain software developer's kit, APP, browser and other teaching tools which can be used to make teaching content, design mobile port, apply APP, call resource and utilize cloud storage space. Knowledge growth and accumulation module covers knowledge li- brary module and interaction module which can be used for interactions between teachers and students, virtual classroom, real-time trend sharing, question asking and answering, classroom doubt solving rate display and feedback evaluation. Knowledge library module is interconnected with cloud database module. Besides, toolkit module can call data from cloud database module, and knowledge library module can call data from interaction module.

Teaching resource cloud platform can call data from of network interactive teaching material is as figure 2 , and the interfaces of network interactive teaching material and Teaching resource cloud platform are as figure 3 .

\section{DEMONSTRATION AND EFFECT OF NETWORK INTERACTIVE TEACHING MATERIAL IN HUMAN RESOURCE MANAGEMENT COURSE}

Human Resource Management is based basic conception, basic theory, procedure and method of human resource management. It takes the functions of human resource management as the principal line, scientifically and reasonably organizes recruitment, development, remuneration, coordination, maintenance, loyalty index and labor relations. In this experiment, experimental control method was mainly applied to gather experimental data. Meanwhile, comparative analysis was conducted for experimental class and control class after the course was over. Statistical survey was adopted to process the data.

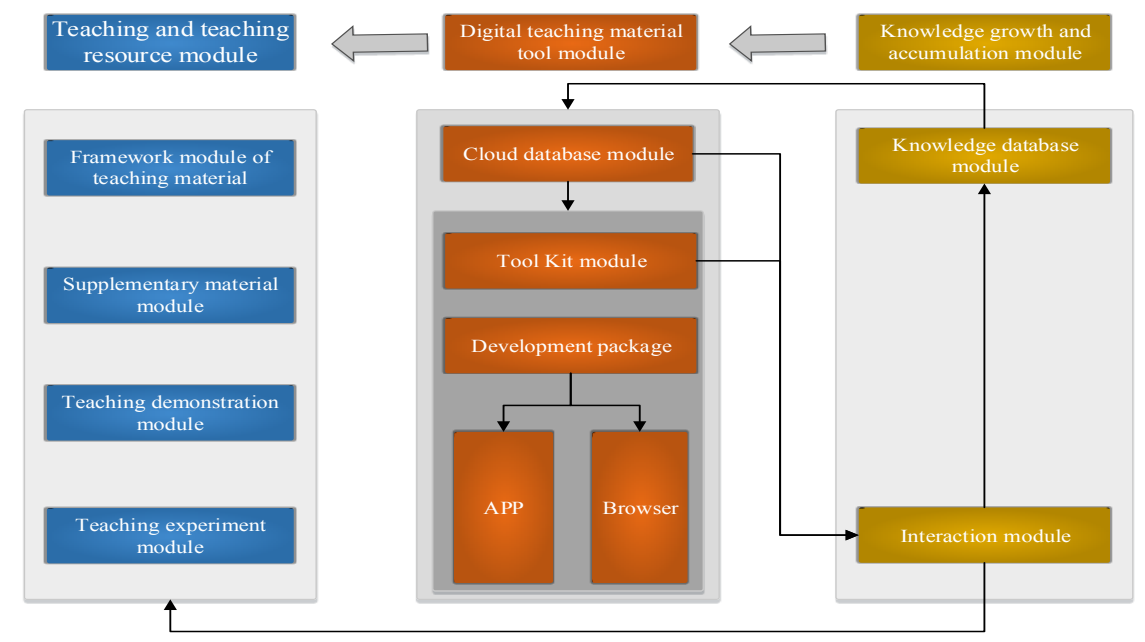

Figure 2. Teaching resource cloud platform can call data from of network interactive teaching material

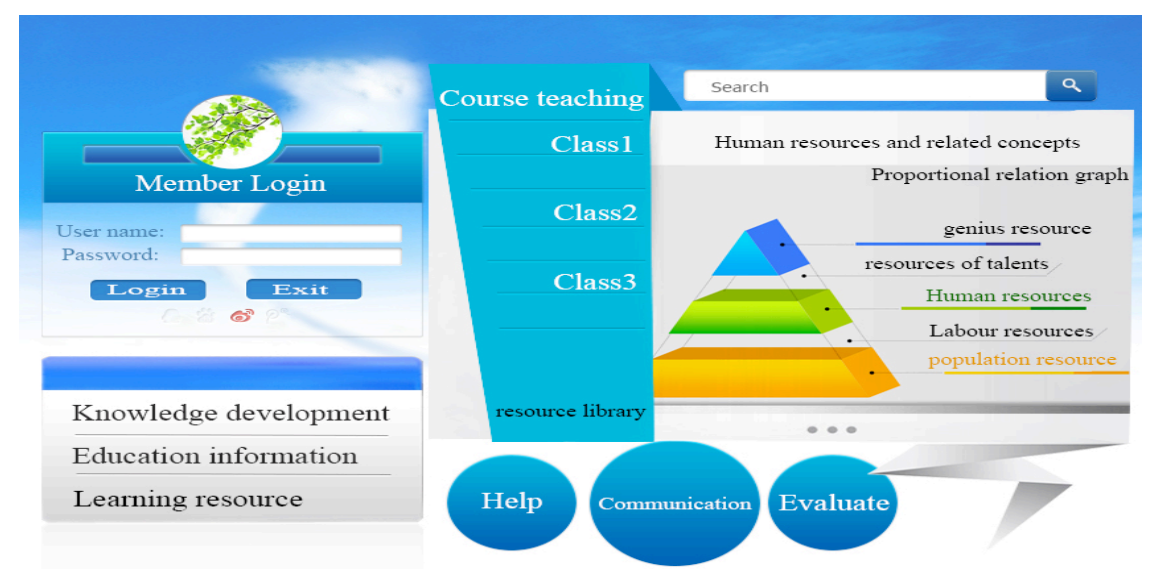

Figure 3. Interfaces of network interactive teaching material and Teaching resource cloud platform 


\section{A. Objects of experiment}

In this paper, Human Resource Management is chosen as the experimental course, with total class hours of 36. 205 students from 4 classes in Grade 2 served as the objects of research, including 104 male students and 101 female students. Their age ranged from 20 and 21, with the average age of 20.5. Class 1 and Class 3 were set as the control group (103 students), while Class 2 and Class 4 were set as the experimental group (102 students). The gender, age and examination scores of students in both groups have no significant difference $(\mathrm{P}>0.1)$. Besides, the basic courses they learned are basically consistent. The experiment conclusions were gained through teaching evaluation data statistics and questionnaire survey results. The cooperation between researchers and practitioners is the foundation of experiment.

(1) Control group. Traditional teaching method was applied for the control group.

(2) Experimental group. Network interactive teaching material was used in the teaching process.

\section{B. Teaching process design}

The objects of experiment learned Human Resource Management by network interactive teaching material and teaching resource platform. Thee administrator of distance education provided teaching material and various teaching resources for students, guided students for study and grasped the course schedule. Students utilized teaching resource platform to achieve group cooperation and independent study, and completed learning effect which conformed to actual conditions and timely feedback.

(1) Dominated by synergetic generation of course knowledge

New and generative reading mode was adopted for the application of network interactive teaching material in Human Resource Management. Students gained experience through reading the teaching material and made corresponding micro-teaching unit. Then, learning process was achieved through the teaching unit designed with other students. Students' earning tool came from teaching resource cloud platform of network interactive teaching material which was mainly used to assist students in finishing the learning task and self-adjusting learning plan.
The data of learning effect evaluation scheme design included students' learning behavior data and in-depth interaction data. Meanwhile, such data as login times, learning duration and task quality were considered.

(2) Supplemented by group help and independent study

Students may participate in network interactive teaching material content building through teaching resource cloud platform, edit and comment teaching material content as well as supplement relevant information. Group help can achieve real role exchange between knowledge producers and consumers as well as between teachers and students.

Besides, course learning process also includes offline classroom interaction and exchange. Students' learning is supervised to some extent to guarantee moderate learning time and cognition energy.

(3) Timely and effective teaching evaluation

Teaching resource cloud platform can achieve comprehensive evaluation of learning interaction, cognition input and classroom performance. Evaluation data come from information collection in learning process and data analysis, including learning situation information, learning behavior data and learning result. Course teaching chart of Management is as figure 4.

\section{Teaching effect evaluation}

After the teaching content for 36 class hours was finished, satisfaction survey was carried out for teaching effect of control class. In addition, questionnaire survey was conducted for teaching effect of experimental class. The evaluation mainly involves 6 aspects: 1 learning activity students participated in most; 2 frequency of microteaching unit making; 3 frequency of active access to cloud platform; 4 resource type used; 5 advantages of network interactive teaching material; 6 defects of network interactive teaching material. 102 questionnaires were distributed and recovered, with recovery rate of $100 \%$. And, effective rate of questionnaires was $100 \%$.

SPSS Amos 21 professional statistical software was used for statistical analysis of teaching satisfaction and effect of both groups. $\chi^{2}$ test was adopted for inter-group comparison, with test level of $\alpha=0.05$.

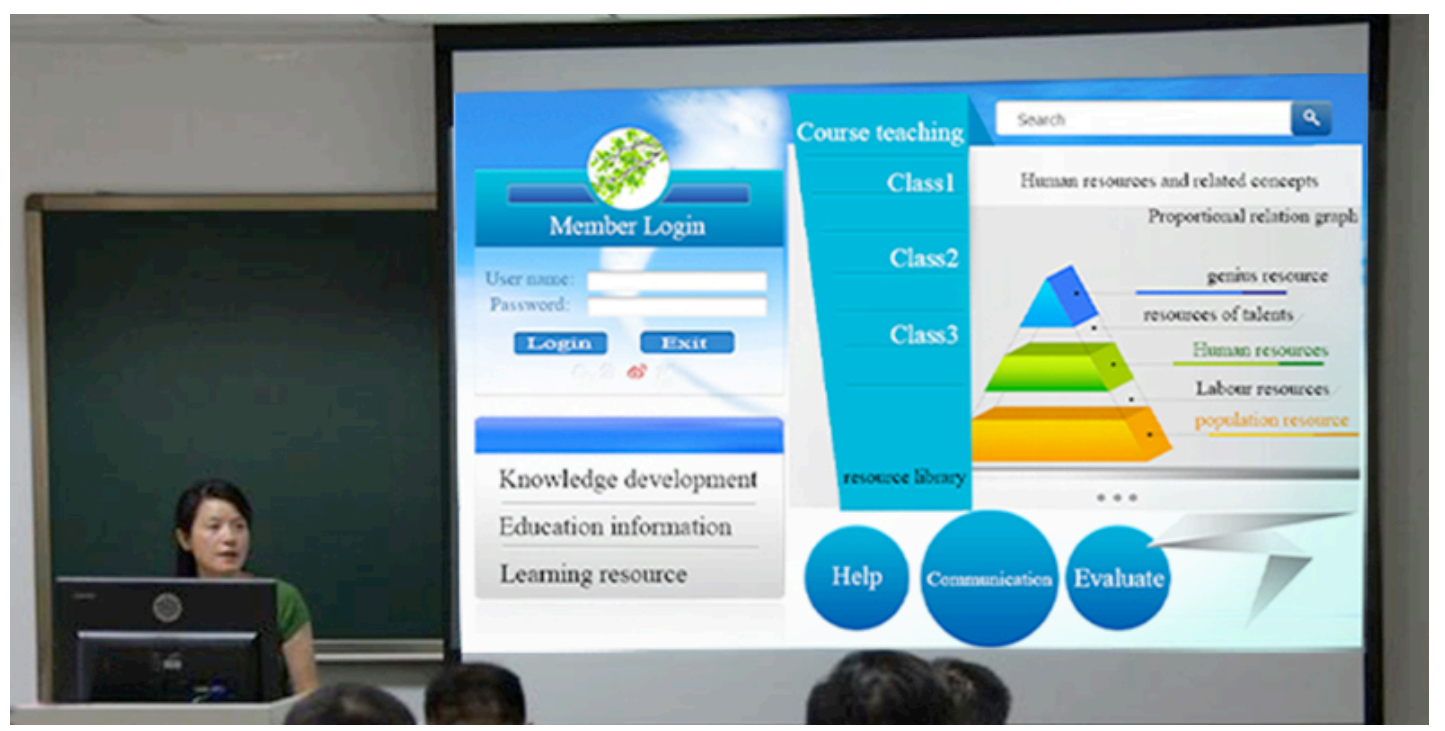

Figure 4. Course teaching scene 


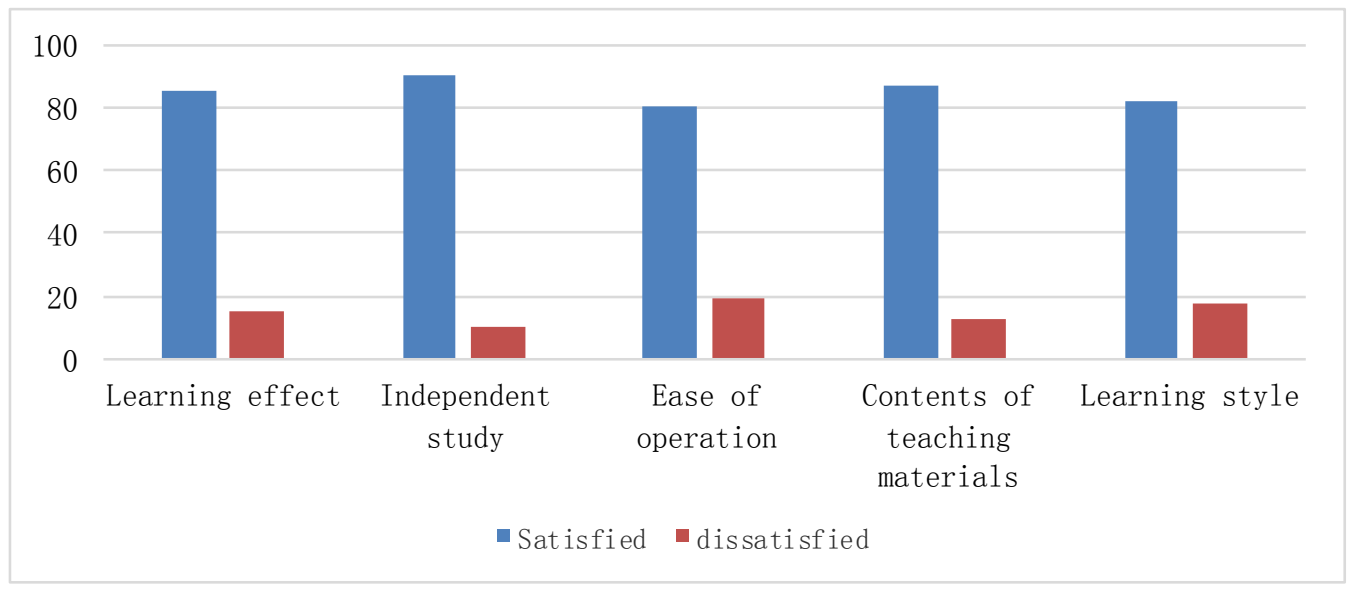

Figure 5. Satisfaction survey results

TABLE I.

STATISTICAL RESULTS OF QUESTIONNAIRE SURVEY

\begin{tabular}{|c|c|c|c|c|c|}
\hline \multirow{3}{*}{$\begin{array}{c}\text { Question } \\
\begin{array}{c}\text { Learning activity you particulate in } \\
\text { most }\end{array}\end{array}$} & \multicolumn{4}{|c|}{ Classification } & \multirow{3}{*}{$\frac{\mathbf{P}}{<0.0001}$} \\
\hline & Independent study & Cooperation & Comment & Others & \\
\hline & $46(45.1)$ & $36(35.29)$ & $12(11.76)$ & $8(7.84)$ & \\
\hline \multirow{2}{*}{$\begin{array}{l}\text { Your frequency of making micro- } \\
\text { teaching unit }\end{array}$} & $2-3$ times & $4-5$ times & Once & & \multirow{2}{*}{$<0.0001$} \\
\hline & $71(69.61)$ & $16(15.69)$ & $15(14.71)$ & & \\
\hline \multirow{2}{*}{$\begin{array}{l}\text { Your frequency of active access to } \\
\text { cloud platform }\end{array}$} & $2-3$ days & 4-5 days & Every day & & \multirow{2}{*}{$<0.0001$} \\
\hline & $69(68.32)$ & $20(19.8)$ & $12(11.88)$ & & \\
\hline \multirow{2}{*}{ Resource type you use most } & Browsing teaching material & Group cooperation & Others & & \multirow{2}{*}{$<0.0001$} \\
\hline & 70 & 20 & 10 & & \\
\hline \multirow{2}{*}{$\begin{array}{l}\text { Advantages of network interactive } \\
\text { teaching material }\end{array}$} & Flexible learning place and form & Intelligence & Abundant resources & Others & \multirow{2}{*}{$<0.0001$} \\
\hline & $46(45.1)$ & $26(25.49)$ & $20(19.61)$ & $10(9.8)$ & \\
\hline \multirow{2}{*}{$\begin{array}{l}\text { Defects of network interactive teach- } \\
\text { ing material }\end{array}$} & Single function & Complex operation & $\begin{array}{l}\text { Contents lack character- } \\
\text { istics }\end{array}$ & Others & \multirow[t]{2}{*}{$<0.0001$} \\
\hline & $39(37.86)$ & $36(34.95)$ & $20(19.42)$ & $8(7.77)$ & \\
\hline
\end{tabular}

\section{Comparative analysis of teaching effect}

As shown in figure 5, the application of network interactive teaching material in Human Resource Management has significant benefit. The students in experimental class show high recognition degree for network interactive teaching material and teaching resource cloud platform. After the study is finished, network interactive teaching material of Human Resource Management is more sound, and students' learning initiative strengthen significantly. Both the teacher and students think highly of network interactive teaching material. The satisfaction degree for learning effect reaches 855 ; the satisfaction degree for independent study is $90 \%$; the satisfaction degree for easy operation is $80 \%$; the satisfaction degree for teaching material content is $87 \%$; the satisfaction degree for learning mode is $82 \%$. Statistical results of questionnaire survey for other items are shown in table 1 .

Table 1 indicates that compared with the control group, course study with network interactive teaching material can greatly facilitate students' practical ability and allround improvement. Most students are satisfied with network interactive teaching material and resource cloud platform $(\mathrm{P}<0.01)$. The frequent learning activities include independent study and cooperative study; most students participate in 2-3 times of teaching unit making; the frequency of access to resource cloud platform is stable. Intelligence of network interactive teaching material and flexible learning mode are widely accepted and satisfying. The teaching mode of control class is rigid, so the teaching effect is relatively poor.

Moreover, the survey shows that single function and complex operation of network interactive teaching material should be concerned. Except multimedia and intelligence, usability of network interactive teaching material should not be ignored. During making network interactive teaching material, media data size should decrease as far as possible and network application should be optimized. Compressing media data size, supporting more media forms and eliminating network system delay can improve the performance of medial application procedure, and users do not need extra operation.

\section{CONCLUSIONS}

The demonstration of network interactive teaching material in Human Resource Management shows that the application of network interactive teaching material has significant effect, and its openness, individuation and mutual help characteristics can effectively solve rigidness, closure and mechanization of traditional teaching material and current online courses. Teaching resource cloud platform in this research supports multiple forms of online study, including online study, mobile study and online exchange etc. Such diversified teaching forms enrich learning contents, make knowledge vivid, simplify teaching difficulty and fully mobilize students' enthusiasm. 
Network system provides adaptation support for learners and offer personalized learning contents for learners according to learning background, learning ability and respective foundation so as to make both parties of education adapt. The improved network interactive teaching material and learning platform can be operated easily, and teaching material content can be updated anytime. Thus, both teachers and students are satisfied with such software. Compared with traditional teaching technology, students and teachers are more willing to accept such new modern teaching technology.

Meanwhile, we have also found that distance education requires learners to adopt network learning mode, master basic learning skills and improve metacognition skills. Current network interactive teaching material and teaching resource platform are in the initial development stage, so such problems as high technical requirement, single function and low operability will still exist in a short term. We need to further discuss and improve these defects.

\section{REFERENCES}

[1] Tam M., "Constructivism, instructional design, and technology: Implications for transforming distance learning," Educational Technology \& Society, vol. 3, no. 2, pp. 50-60, April 2000.

[2] Choudhary N., Sudarshan S., Singh N.K., "A study of locus of control among distance learning pursuing professional in Bangalore," Middle East Journal of Management, vol. 1, no. 4, pp. 342361, December 2014. http://dx.doi.org/10.1504/MEJM.2014. 066054

[3] Bocconi S., \& Trentin G., "Modelling blended solutions for higher education: teaching, learning, and assessment in the network and mobile technology era," Educational Research and Evaluation, vol. 20, no. 7-8, pp. 516-535, January 2015. http://dx.doi.org/10.1080/13803611.2014.996367

[4] Toyama H., Inoue R., Ito Y, Sakamoto C., Ishikawa T., Eda T., et al., "Electronic teaching materials for inter-professional education in a college of medical professionals," Studies in health technology and informatics, vol. 192, pp. 1119-1119, August 2012.

[5] Ismail N., Albakri M. A., Safinas I., Ismail N., \& Hussin S., "Preservice teachers' reflection on the use of self-developed english language teaching materials for english as a second language students," International Journal of Pedagogy and Curriculum, vol. 20, no. 4, pp. 35-51, August 2014.
[6] Damanakis A., Blaum W.E., Stosch C., Lauener H., Richter S., Schnabel K.P., "Simulator Network project report: a tool for improvement of teaching materials and targeted resource usage in Skills Labs," GMS Zeitschrift fur medizinische Ausbildung, vol. 30, no. 1, pp. Doc4-Doc4, February 2013.

[7] Pepin B., Gueudet G., Yerushalmy M, Trouche L., Chazan D., " $e$ textbooks in/for teaching and learning mathematics: A disruptive and potentially transformative educational technology," Handbook of International Research in Mathematics Education. Third edition, 2015: 636-661.

[8] Li F.M., Xiao F., "Primary Investigation of Interactive E-textbook by Taking Tablet PC as Reading Device," Publishing Journal, vol. 20, no. 2, pp. 86-89, April 2012.

[9] Lin J.F., Li H.Q., Huang H.H., "Interactive Digital Teaching Material: New Form of Digital Teaching Resource," Educational Information Technology, vol. 3, no. 6, pp. 3-7, June 2013.

[10] Yu S.Q., Wan H.P., Cui J.J., "Emergent Curriculum Design and Implementation Based on the Learning Cell System," China Educational Technology, vol. 22, no. 6, pp. 7-16, June 2015.

[11] Li G., "Student-centered 'Human Resource Management' Teaching Mode Reform," Education and Vocation, vol. 48, no. 17, pp. 154-155, September 2014.

[12] Armenteros M., Liaw S.S., Fernández M., Díaz R.F., Sánchez R.A., "Surveying FIFA instructors' behavioral intention toward the Multimedia Teaching Materials," Computers \& Education, vol. 61, pp. 91-104, February 2013. http://dx.doi.org/10.1016/j.compedu. 2012.09.010

[13] Battiato S., Emmanuel S., Ulges A., Worring M., "Multimedia in forensics, security, and intelligence," MultiMedia, IEEE, vol. 19, no. 1, pp. 17-19. January 2012. http://dx.doi.org/10.1109/MMUL. $\underline{2012.10}$

\section{AUTHORS}

Xiaobo JIA is an associate professor of Tourism and Cultural Art Depart of Chongqing Youth Vocational \& Technical College, Chongqing 400712, China. His research interests include Network Interactive Teaching Materials and distance education.jiaxiaobo33@yeah.net)

Juying HUANG is a professor of Institution of Technology of Chongqing City Management Vocational College, Chongqing 401331, China. Her research interests include Management and distance education Course. (researcher22@yeah.net)

Submitted 29 March 2016. Published as resubmitted by the authors 07 April 2016. 